\title{
ARTICLES
}

\section{Changes in the Expression of Nephrin Gene and Protein in Experimental Diabetic Nephropathy}

\author{
Petri Aaltonen, Pauliina Luimula, Eva Åström, Tuula Palmen, Tina Grönholm, \\ Eeva Palojoki, Ilkka Jaakkola, Heikki Ahola, Ilkka Tikkanen, and Harry Holthöfer
}

Haartman Institute (PA, PL, EA, TP, HA, HH), Department of Bacteriology and Immunology, University of Helsinki, Helsinki; Department of Medicine (TG, EP, IT), Helsinki University Central Hospital and Minerva Institute for Medical Research, Helsinki; and University of Turku (IJ), Turku, Finland

SUMMARY: Diabetic nephropathy is a major complication of diabetes leading to thickening of the glomerular basement membrane, glomerular hypertrophy, mesangial expansion, and overt renal disease. The pathophysiologic mechanisms of diabetic nephropathy remain poorly understood. Nephrin is a recently found podocyte protein crucial for the interpodocyte slit membrane structure and maintenance of an intact filtration barrier. Here we have assessed the role of nephrin in two widely used animal models of diabetes, the streptozotocin model of the rat and the nonobese diabetic mouse. In both models, the expression levels of nephrin-specific mRNA as determined by real-time quantitative polymerase chain reaction increased up to two-fold during several weeks of follow-up. Immunohistochemical stainings revealed nephrin also more centrally within the glomerular tuft along with its preferential site in podocytes. Interestingly, as detected by immunoblotting, nephrin protein was also found in the urine of streptozotocin-induced rats. We conclude that nephrin is connected to the early changes of diabetic nephropathy and thus may contribute to the loss of glomerular filtration function. (Lab Invest 2001, 81:1185-1190).

$T$ he molecular pathogenesis of glomerular diseases with proteinuria is poorly known, although increasing evidence suggests a key role for the podocytes in the permeability changes at the glomerular filtration barrier. Kestilä et al (1998) recently cloned a new gene NPHS1 mutated in the massively proteinuric congenital nephrotic syndrome of the Finnish type (CNF) patients. We and others have shown that the respective protein product, nephrin, localizes mainly to the interpodocyte filtration slit area, although some nephrin is always present at the lateral podocyte membranes (Holthöfer et al, 1999a; Ruotsalainen et al, 1999). Our results have further shown alternative splicing of nephrin-specific mRNA (Holthöfer et al, 1999a) and changes of nephrin mRNA levels during experimental renal diseases closely paralleled by loss of nephrin protein into urine (Luimula et al, 2000). In vivo injection of antinephrin antibodies into the rat results in transient proteinuria as shown by Orikasa et al (1988), and recurrence of posttransplantation nephrosis in

Received November 29, 2000.

This work was supported by grants from the Sigrid Jusélius Foundation, and research grants from Helsinki University Central Hospital, the Finnish Diabetes Association, and Finnish Foundation for Cardiac Diseases. Address reprint requests to: Dr. Harry Holthöfer, Senior Scientist of the Finnish Academy, Haartman Institute, Department of Bacteriology and Immunology, PB 21 (Haartmaninkatu 3), FIN-00014 University of Helsinki, Helsinki, Finland. E-mail: Harry.Holthofer@Helsinki.Fi
CNF patients is associated with elevated circulating antinephrin antibody levels (SX Wang, T Palmen, $\mathrm{H}$ Ahola, ML Solin, P Luimula, and H Holthöfer, unpublished data).

Because diabetic nephropathy is a major cause of glomerular injury, scarring, and proteinuria (Cooper, 1998) we wanted to analyze whether nephrin participates in the molecular pathogenesis of this group of diseases. For this purpose, both the classic streptozotocin model of rat diabetes and spontaneously diabetic nonobese diabetic (NOD) mice were used. Streptozotocin (STZ) induces an insulin-dependent diabetes mellitus by selectively impairing the insulin production in pancreatic beta cells and thus mimics type I diabetes (Hebden et al, 1986; Junod et al, 1967). NOD mice are also widely used as a model for human insulin-dependent diabetes mellitus (IDDM) (Hebden et al, 1986). The spontaneous development of diabetes in NOD mice is caused by an autoimmune destruction of pancreatic beta cells (Tisch et al, 1993). Infiltration of the islets of Langerhans by dendritic cells and macrophages (Dahlen et al, 1998), followed by $\mathrm{T}$ lymphocytes and B lymphocytes (Miyazaki et al, 1985), is seen at 5 to 6 weeks of age in the NOD pancreas. After this, a slowly advancing T cell-mediated destruction of beta cells starts and manifests as diabetes at around 3 to 6 months when most of the beta cells (85\%-90\%) are destroyed (Bach 1995; Delovitch and Singh, 1997). Eight weeks after onset of diabetes, the early signs of nephropathy, including an increase in 
glomerular surface area with moderate mesangial sclerosis and albuminuria, can be observed (Doi et al, 1990)

\section{Results}

\section{Blood and Urine Samples}

At Days 10 to 14 after the induction of diabetes, mean ( \pm SEM) blood sugar value before the daily insulin dose was $26.3 \pm 2.0 \mathrm{mmol} / \mathrm{l}$ in the STZ-injected rats and 5.6 $\pm 0.3 \mathrm{mmol} / \mathrm{l}(p<0.001)$ in the vehicle-injected controls. All STZ-induced animals developed significant proteinuria and glucosuria after disease induction as shown in (Fig. 1). As the quantitation by nephelometry indicates, albuminuria in STZ-treated rats started at Week 4 after induction and had increased rapidly by 6 and 16 weeks (Fig. 2). The urinary albumin/creatinine ratio indicated a remarkable damage to the glomerular filter in all STZ-treated animals throughout the follow-up period (Fig. 3).

\section{Nephrin in Urine}

Free nephrin, as detected by immunoblotting, was found in the urine of STZ-induced rats already at 4 weeks and was at the maximum at 6 weeks (Fig. 4).

\section{mRNA Levels of Nephrin}

According to TaqMan real-time PCR analysis of nephrin-specific mRNA, the glyceraldehyde-3phosphatedehydrogenase (GAPDH)-normalized nephrin levels of diabetic rats had increased on the average by $50 \%$ already at 4 weeks after induction as compared with control rats. This high expression continued until 16 weeks (Fig. 5).

A similarly significant elevation of nephrin-specific mRNA level was seen in the NOD mice compared with the normal mice. Thus, a more than 2-fold increase in nephrin mRNA expression was observed already in 3-week-old NOD mice, and the expression level con-

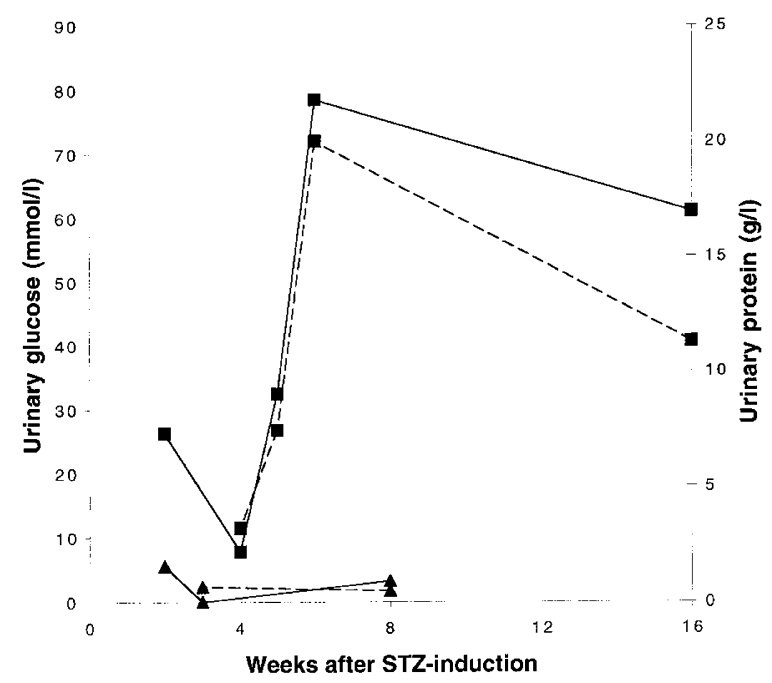

Figure 1.

Semiquantitation of urinary glucose (solid line) and protein (broken line) in streptozotocin (STZ)-treated rats ( $\mathbf{\square})$ and controls $(\boldsymbol{\Delta})$.

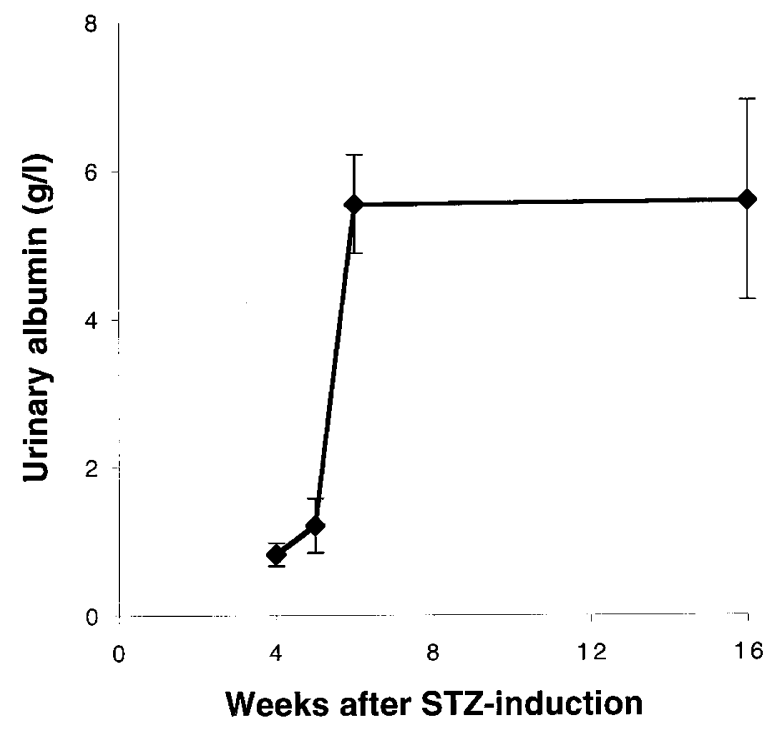

Figure 2.

Urinary albumin in STZ-treated rats measured at Weeks 4, 5, 6, and 16. Plotted values are means \pm SEM of $8,5,3$, and 5 rats at each time point, respectively.

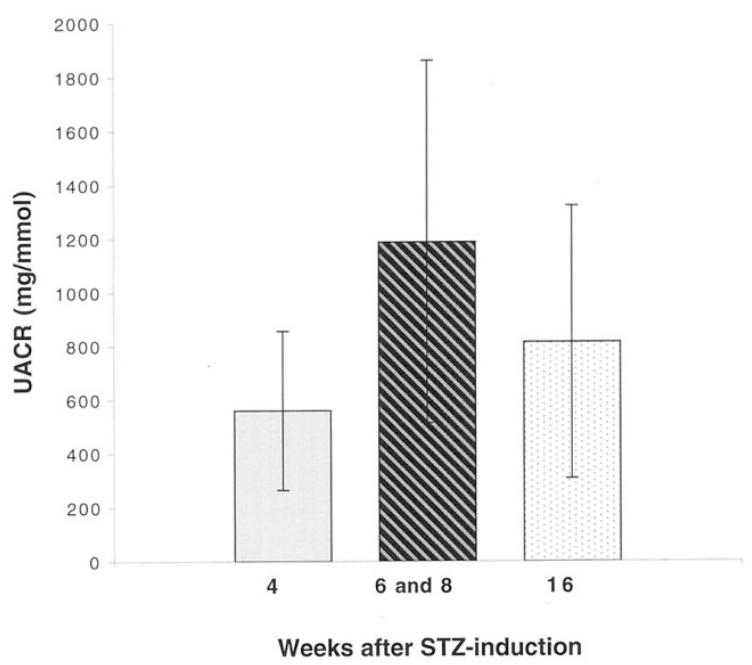

Figure 3.

Urinary albumin/creatinine ratio (UACR) of STZ-treated rats at 4,6 or 8 , and 16 weeks.

tinued to increase until 6 weeks of age. A slight decrease, instead, could be seen in the nephrin mRNA expression level at 10 weeks (Fig. 6).

\section{Altered Localization of Nephrin}

As seen by light microscopy, staining for nephrin yields an epithelial-like pattern in glomeruli, with cells facing the urinary space showing distinct reactivity, whereas the innermost glomerular tuft areas remain negative (Fig. 7A). After 8 and 16 weeks of streptozotocin induction, additional nephrin localization was observed (Fig. 7B). Typically, a less intense reactivity at the epithelial aspect was seen, whereas more central localization and deposits apparently around 


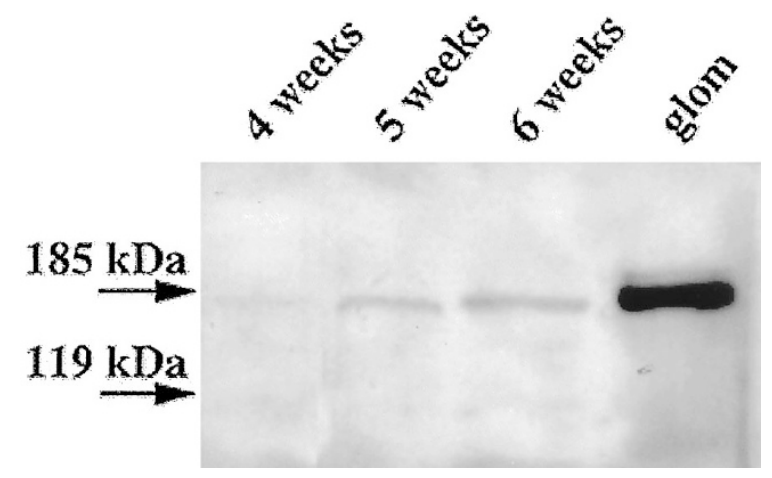

Figure 4.

Immunoblotting analysis of nephrin with polyclonal anti-nephrin antibody directed at the extracellular domain. Samples are urine of STZ-treated rats at Weeks 4,5 , and 6 . Glomerular lysate of normal rat is shown as a positive control $(\mathrm{glom})$. Molecular mass markers are shown to the left.

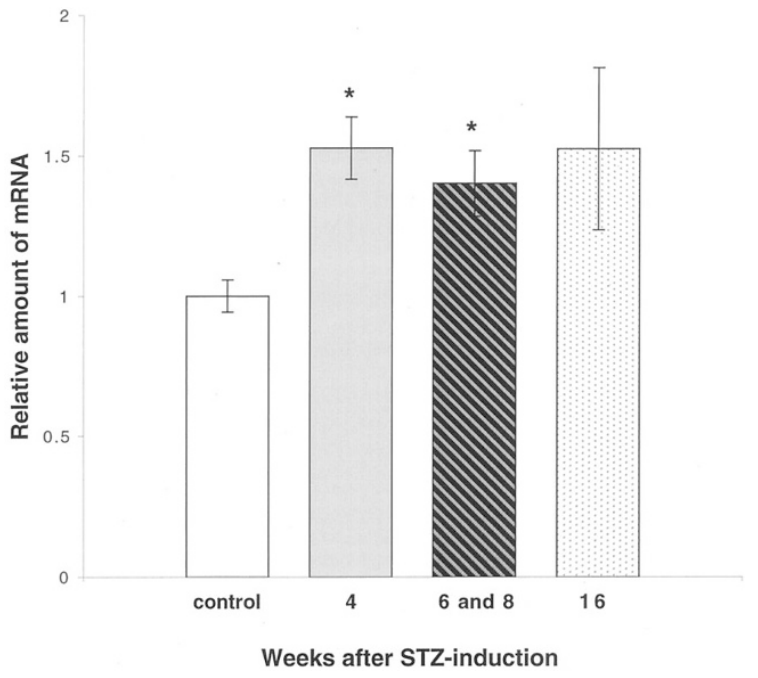

Figure 5.

Relative levels of nephrin mRNA in STZ-treated rats after $4(n=2), 6$ or $8(n=4)$, and $16(n=5)$ weeks compared with the control rats $(n=3)$. Plotted values are the relative nephrin mRNA levels normalized by glyceraldehyde-3-phosphate dehydrogenase (GAPDH) mRNA levels and are expressed as mean \pm SEM. ${ }^{*} p<0.05$ versus control.

capillaries were increasingly observed in the STZtreated rats (Fig. 7B).

\section{Discussion}

Here, we show an increase in nephrin-specific mRNA and changes in the respective protein expression along with a loss of glomerular filtration function at the early stages of both the STZ model of the rat and in the NOD mice. Furthermore, an early loss of nephrin in the urine was seen. Together with our previous findings of nephrin regulation and loss to urine, particularly in the puromycin model of the rat, these results indicate that nephrin is involved in the maintenance of an intact filtration barrier.

Nephrin appears as the first true functional molecule of the interpodocyte filtration slits (Holthöfer et al, 1999a; Holzman et al, 1999; Ruotsalainen et al, 1999). In support of this, the nephrin gene was first cloned

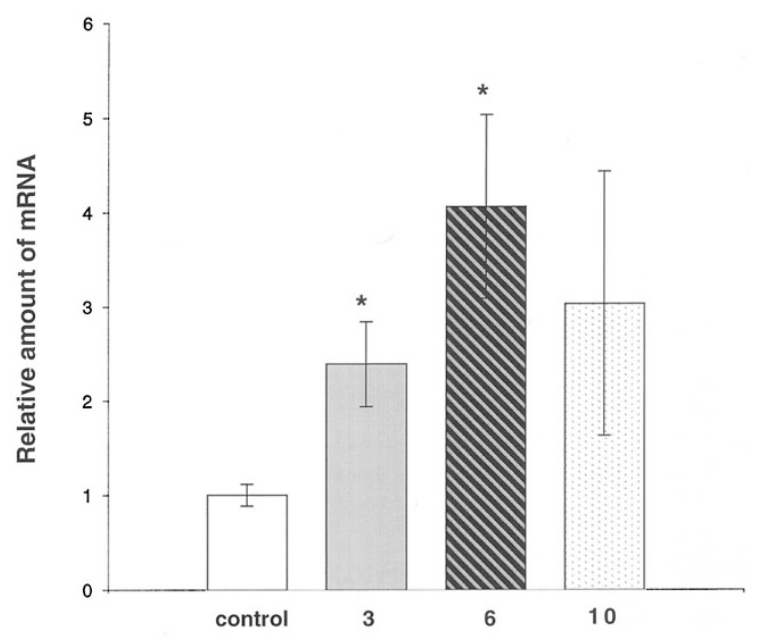

Age of NOD mice (weeks)

Figure 6.

Relative levels of nephrin mRNA in nonobese diabetic (NOD) mice at 3, 6, and 10 weeks of age compared with normal mice. Plotted values are the relative nephrin mRNA levels normalized by GAPDH mRNA levels and are expressed as mean \pm SEM of three mice in each group. ${ }^{*} p<0.05$ versus control.

from the massively proteinuric CNF patients (Kestilä et al, 1998). Based on the filtration slit area localization, Putaala et al (2000) have proposed a zipper-like lattice organization of this structure, in which nephrin forms a backbone extending from adjacent podocyte foot processes. Whether other proteins in addition to nephrin are needed for the slit membrane assembly remains to be discovered. However, our results, both with rat (Ahola et al, 1999) and human (Holthöfer et al, 1999a) nephrin, show that nephrin is additionally found at the lateral podocyte membranes. Furthermore, in puromycin aminonucleoside nephrosis (PAN) nephritis of the rat, an increase in the plasmalemmal nephrin, with simultaneous decrease from the slit, is seen (Luimula et al, 2000). Interestingly, both in the human (Holthöfer et al, 1999a) and rat (Ahola et al, 1999), alternatively spliced nephrin yields a mRNA variant that is missing the transmembrane-spanning domain, suggesting an existence of a soluble form of nephrin. Our results in the PAN model suggest that the soluble splice variant is predominantly lost in the urine (Luimula et al, 2000). Whether it is similarly the preferential form of nephrin found in the urine in diabetic nephropathy remains to be analyzed in detail.

In diabetes a poor glycemic balance is related to secondary damages such as retinopathy, neuropathy, and nephropathy (Odoni and Ritz 1999). Despite an immense medical impact and extensive studies, the exact molecular pathogenesis of diabetic nephropathy, particularly the loss of the functional glomerular filter, remains to be characterized.

Previous studies of the mechanisms of diabetic nephropathy have revealed multiple changes in cells participating in the maintenance of glomerular basement membrane (GBM) (Ha and Kim, 1999). Those changes include, eg, increased production of transforming growth factor- $\beta$ (TGF- $\beta$ ), fibronectin, and type 

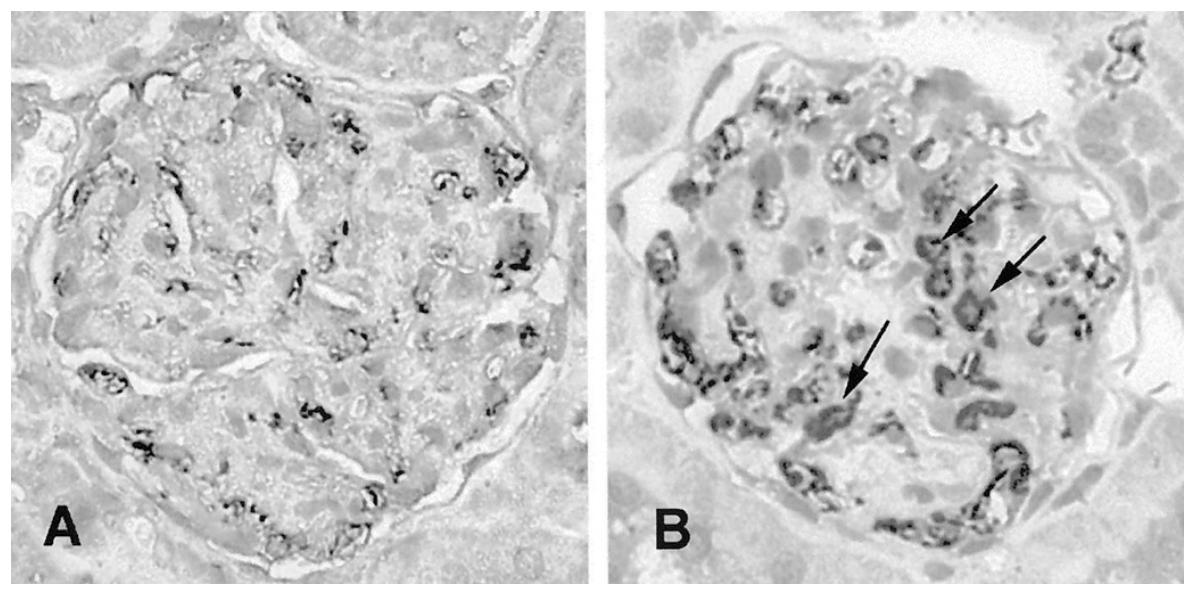

Figure 7.

Immunohistochemical staining of paraffin-embedded kidneys of the normal (A) and STZ-treated (B) rat with polyclonal anti-nephrin antibody. Note the altered staining pattern in B (arrows). Magnification, $\times 640$.

IV collagen and disturbed function of the $\mathrm{Na}^{+}-\mathrm{K}^{+}$ATPase (Hoffman et al, 1998; Koya et al, 1997). Interestingly, the changes in GBM, including an increase in type IV collagen and fibronectin, may be caused directly by hyperglycemia, increase of reactive oxygen species, and nonenzymatic glycosylation (Odoni and Ritz, 1999). These changes are associated with the activation of protein kinase $\mathrm{C}$ (PKC), which is believed to mediate many of the manifestations of diabetic nephropathy (Koya and King, 1998; Scivittaro et al, 2000; Suzuki and Miyata, 1999). Our results show that activation of PKC causes substantial increase of nephrin mRNA and respective protein production in cultured cells expressing nephrin (Wang et al, 2001). This finding supports our result of increased nephrin mRNA levels in the early stages of nephropathy. Instead, in a study of the late stages of the STZ model (follow-up period up to 6 months) without daily insulin injections, our results have shown a uniform decrease in nephrin mRNA levels, possibly reflecting scarring and loss of functional podocytes (Gilbert, Aaltonen, Tikkanen, Cox, Cooper, Palmen, Luimula, Kelly, and Holthöfer, unpublished data).

The altered localization of nephrin into the more central areas of the glomerular tuft along with disease progression is intriguing. Even if soluble nephrin is lost in the urine, some of it may apparently gain access to more central parts of the glomeruli against the flow of the stream from the podocytes. Similar upstream movement is seen, eg, in vascular endothelial growth factor C (VEGF-C) produced by the podocytes moving to the respective receptors at the glomerular endothelium (Esser et al, 1998).

Together, these results suggest that nephrin is associated with the initial stages of the loss of the permeability barrier in diabetic nephropathy. The functional changes are seen along with the increased mRNA levels and an altered localization pattern of nephrin within the glomerulus. Whether specific splicing variants are involved remains under study.

\section{Materials and Methods}

\section{Induction of Diabetes with Streptozotocin in Rats}

Male Wistar rats (University of Helsinki, Helsinki, Finland), aged 12 weeks and weighing between 200 and $250 \mathrm{~g}$, were randomized to receive STZ $(n=14$; Sigma Chemical Company, St. Louis, Missouri), $40 \mathrm{mg} / \mathrm{kg}$, or citrate buffer ( $n=3$; nondiabetic controls) by intravenous injection in the tail vein. Only diabetic rats with plasma glucose levels over $17 \mathrm{mmol} / \mathrm{l}$, measured 2 to 4 days after STZ injection, were included in the study. To prevent ketoacidosis and to promote weight gain without rendering the animals euglycemic, diabetic rats were given long-acting insulin (Humutard Ultra; Lilly, Paris, France) subcutaneously at a dose of 4 units daily. Plasma glucose values also remained elevated in all diabetic rats when controlled 10 to 14 days after induction of diabetes and randomly thereafter. Animals were housed at a constant room temperature in a 12-hour light/dark cycle with free access to standard rat chow and water ad libitum. Kidneys were taken under sodium pentobarbital anesthesia (75 $\mathrm{mg} / \mathrm{kg}$, ip) at 8,14 , and 16 weeks. Half of each kidney was fixed in $4 \%$ neutral buffered paraformaldehyde, and the rest of the kidney was snap-frozen in isopentane and stored at $-80^{\circ} \mathrm{C}$ until processed further. The Helsinki University Central Hospital Animal Ethics Committee and the Provincial State Office of Southern Finland approved the experimental procedures.

\section{Nonobese Diabetic Mice}

In the colony of NOD mice, the cumulative incidence of diabetes by 180 days of age was $66 \%$ in females and $40 \%$ in males. This colony of NOD mice was bred and maintained under specific pathogen-free conditions in the animal facilities of the University of Turku (Turku, Finland). The onset of diabetes within the colony was followed by weekly measurements of urinary glucose (Glucotest; Boehringer Mannheim, Mannheim, Germany). The samples that were positive 
for urinary glucose were verified with blood glucose measuring (MediSense Precision Plus; Medisense, Inc., Abingdon, United Kingdom) and a value of 14.6 $\mathrm{mmol} / \mathrm{l}$ was considered diabetic.

\section{Urine and Blood Samples}

Blood glucose levels were determined using the Arkray Glucocard Test Strip II (KDK Corporation, Kyoto, Japan). Urinary protein and glucose levels were semiquantitated with Uristix dry chemistry strips (Boehringer Mannheim) according to the manufacturer's instructions. Grading for protein was negative, slight $(<0.3 \mathrm{~g} / \mathrm{l}), 1+(>0.3 \mathrm{~g} / \mathrm{l}), 2+(>1.0 \mathrm{~g} / \mathrm{l}), 3+(>3.0$ $\mathrm{g} / \mathrm{l})$, or $>20.0 \mathrm{~g} / \mathrm{l}$; and for glucose: negative, $1+(>5.5$ $\mathrm{mmol} / \mathrm{l}), 2+(>14 \mathrm{mmol} / \mathrm{l}), 3+(>28 \mathrm{mmol} / \mathrm{l}),>55$ $\mathrm{mmol} / \mathrm{l}$, or $>111 \mathrm{mmol} / \mathrm{l}$. Urine samples for determination of urinary albumin/creatinine ratio (UACR) (Mogensen et al, 1995) were collected at 4, 6, 8, and 16 weeks after induction of diabetes by palpation and gentle pressing of the urinary bladder. The urine concentrations of creatinine were measured routinely at a local unit of clinical chemistry $(\mathrm{HUCH}$, Helsinki, Finland). Albuminuria was verified with nephelometry (Behring Nephelometer 100 analyzer; Behringwerke, Marburg, Germany).

\section{RNA Isolation and Reverse Transcription}

Total cortical RNA was extracted from the frozen pieces of kidney tissue $(50-150 \mathrm{mg})$ with a single-step acid guanidium thiocyanate-phenol-chloroform procedure using Trizol reagent (Invitrogen Ltd., Paisley, Scotland) according to the manufacturer's instructions. The isolated RNA was then incubated with RNase free DNase I (Promega, Madison, Wisconsin) for 30 minutes in $37^{\circ} \mathrm{C}$ together with human placental RNase inhibitor (Promega) to remove traces of genomic DNA. Complementary DNA was synthesized with the Moloney Murine Leukemia Virus reverse transcriptase (M-MLV RT, Promega) from $10 \mu \mathrm{g}$ of DNasetreated total RNA in the presence of oligo $\mathrm{dT}_{15}$-primer (Boehringer Mannheim) and an RNase inhibitor as previously described (Holthöfer et al, 1999b).

\section{Real-Time Quantitative PCR}

A novel real-time quantitative PCR detection method (TaqMan technology; PE Applied Biosystems, Foster City, California) used in this study is accurate for measuring quantitatively low levels of RNA not detectable with northern blot. The TaqMan method is based on the use of a fluorescent-labeled probe designed for the sequence between the PCR primers and the exonuclease activity of Taq polymerase. The probe is labeled with a reporter dye (FAM or VIC, PE Applied Biosystems) at its $5^{\prime}$ end and a quencher dye (TAMRA, PE Applied Biosystems) at its $3^{\prime}$ end. When the probe is hybridized to target sequence, it is intact, and the reporter dye remains quenched. In each cycle of amplification, the Taq polymerase releases increasing amounts of reporter dye proportional to the number of target sequences. The fluorescence is measured with the appropriate instrumentation (PE Biosystems model 7700) (Holland et al, 1991; Laurendeau et al, 1999).

In the Taqman PCR, a FAM-labeled probe 2735UP (5'-ccctcttcaaatgcacggccacca- 3 ') was used, together with primers $2709 \mathrm{U}$ (5'-taatgtgtctgcggcccag-3') and 2783L (5'-ttggtgtggtcagagccaag-3'), for the amplification of rat nephrin, and primers 2636U (5'atctccaagaccccaggtacaca-3') and 2817L (5'agggtcagggcggctgat-3') for mouse nephrin. GAPDH served as an endogenous control. GAPDH values for diabetic mice and rats were used to normalize the amounts of nephrin.

\section{Immunoblotting}

Urine samples $(10 \mu l)$ were loaded into $8 \%$ SDS polyacrylamide gel with reducing loading buffer. Proteins were electrophoresed with reducing conditions and electrotransferred to nitrocellulose membrane (Scleicher \& Schuell, Dassel, Germany) as described previously (Reivinen et al, 1994). To prevent nonspecific binding, the membrane was blocked by incubation in 3\% bovine serum albumin. Primary polyclonal rabbit anti-nephrin antibody directed at the extracellular part of nephrin (Glomega, Inc., Helsinki, Finland) (Ahola et al, 1999), used at 1:300 (diluted in PBS/0.1\% Tween-20), was applied for 60 minutes at room temperature. After several rinses with PBS/0.1\% Tween20, a secondary antibody (horseradish peroxidaseconjugated swine anti-rabbit immunoglobulins; Dako, Glostrup, Denmark) was used at 1:2000.

\section{Immunohistochemistry}

Sagittally cut kidneys were fixed with $4 \%$ paraformaldehyde (in PBS) and embedded routinely in paraffin. For stainings, $3-\mu \mathrm{m}$ sections were cut and deparaffinized, rehydrated, microwave-antigen unmasked, and incubated with $3 \%$ hydrogen peroxide methanol to block endogenous peroxidase activity. After several washes in PBS, the sections were blocked with 10\% nonimmune goat serum. The primary polyclonal antibodies used were against the extracellular part of nephrin (dilution 1:50 and incubation 60 minutes). After a thorough rinsing with PBS/0,05\% Tween-20, the sections were incubated for 10 minutes in biotinylated secondary antibody against rabbit immunoglobulins. The sections were then incubated in streptavidin-peroxidase after mixing with substratechromogen. Slides were counterstained with hematoxylin and mounted. All stages were performed according to instructions for the peroxidase staining with a Histostain-DS kit (Zymed Laboratories, Inc., San Francisco, California).

\section{Statistics}

The normalized values of nephrin-mRNA are averages of three to four runs and are shown as mean \pm SEM. The significance was tested using the Student's $t$ test. A $p$ value $<0.05$ was considered significant. 


\section{References}

Ahola H, Wang SX, Luimula P, Solin ML, Holzman LB, and Holthofer $\mathrm{H}$ (1999). Cloning and expression of the rat nephrin homolog. Am J Pathol 155:907-913.

Bach JF (1995). Insulin-dependent diabetes mellitus as a beta-cell targeted disease of immunoregulation. J Autoimmun 8:439-463.

Cooper ME (1998). Pathogenesis, prevention, and treatment of diabetic nephropathy. Lancet 352:213-219.

Dahlen E, Dawe K, Ohlsson L, and Hedlund G (1998). Dendritic cells and macrophages are the first and major producers of TNF-alpha in pancreatic islets in the nonobese diabetic mouse. J Immunol 160:3585-3593.

Delovitch TL and Singh B (1997). The nonobese diabetic mouse as a model of autoimmune diabetes: Immune dysregulation gets the NOD (erratum appears in Immunity 8:531). Immunity 7:727-738.

Doi T, Hattori M, Agodoa LY, Sato T, Yoshida H, Striker LJ, and Striker GE (1990). Glomerular lesions in nonobese diabetic mouse: Before and after the onset of hyperglycemia. Lab Invest 63:204-212.

Esser S, Lampugnani MG, Corada M, Dejana E, and Risau W (1998). Vascular endothelial growth factor induces VEcadherin tyrosine phosphorylation in endothelial cells. J Cell Sci 111:1853-1865.

$\mathrm{Ha} \mathrm{H}$ and Kim KH (1999). Pathogenesis of diabetic nephropathy: The role of oxidative stress and protein kinase C. Diabetes Res Clin Pract 45:147-151.

Hebden RA, Gardiner SM, Bennett T, and MacDonald IA (1986). The influence of streptozotocin-induced diabetes mellitus on fluid and electrolyte handling in rats. Clin Sci 70:111-117.

Hoffman BB, Sharma K, and Ziyadeh FN (1998). Potential role of TGF-beta in diabetic nephropathy. Miner Electrolyte Metab 24:190-196.

Holland PM, Abramson RD, Watson R, and Gelfand DH (1991). Detection of specific polymerase chain reaction product by utilizing the $5^{\prime}-3^{\prime}$ exonuclease activity of Thermus aquaticus DNA polymerase. Proc Natl Acad Sci USA 88: 7276-7280.

Holthöfer H, Ahola H, Solin M-L, Wang S, Luimula P, Miettinen A, and Kerjaschki D (1999a). Nephrin localizes at the podocyte filtration area and is characteristically spliced in the human kidney. Am J Pathol 155:1681-1687.

Holthöfer H, Kretzler M, Haltia A, Solin ML, Taanman JW, Schagger H, Kriz W, Kerjaschki D, and Schlondorff D (1999b). Altered gene expression and functions of mitochondria in human nephrotic syndrome. FASEB J 13:523-532.

Holzman LB, St John PL, Kovari IA, Verma R, Holthofer H, and Abrahamson DR (1999). Nephrin localizes to the slit pore of the glomerular epithelial cell. Kidney Int 56:1481-1491.

Junod A, Lambert AE, Orci L, Pictet R, Gonet AE, and Renold AE (1967). Studies of the diabetogenic action of streptozotocin. Proc Soc Exp Biol Med 126:201-205.

Kestilä M, Lenkkeri U, Mannikkö M, Lamerdin J, McCready P, Putaala H, Ruotsalainen V, Morita T, Nissinen M, Herva R, Kashtan C, Peltonen L, Holmberg C, Olsen A, and Tryggvason K (1998). Positionally cloned gene for a novel glomerular protein-nephrin-is mutated in congenital nephrotic syndrome. Mol Cell 1:575-582.
Koya D, Jirousek MR, Lin YW, Ishii H, Kuboki K, and King GL (1997). Characterization of protein kinase $C$ beta isoform activation on the gene expression of transforming growth factor-beta, extracellular matrix components, and prostanoids in the glomeruli of diabetic rats. J Clin Invest 100:115126.

Koya D and King GL (1998). Protein kinase C activation and the development of diabetic complications. Diabetes 47 : 859-866.

Laurendeau I, Bahuau M, Vodovar N, Larramendy C, Olivi M, Bieche I, Vidaud M, and Vidaud D (1999). TaqMan PCRbased gene dosage assay for predictive testing in individuals from a cancer family with INK4 locus haploinsufficiency. Clin Chem 45:982-986.

Luimula P, Ahola H, Wang SX, Solin ML, Aaltonen P, Tikkanen I, Kerjaschki D, and Holthofer H (2000). Nephrin in experimental glomerular disease. Kidney Int 58:1461-1468.

Miyazaki A, Hanafusa T, Yamada K, Miyagawa J, FujinoKurihara H, Nakajima H, Nonaka K, and Tarui S (1985). Predominance of $\mathrm{T}$ lymphocytes in pancreatic islets and spleen of pre-diabetic non-obese diabetic (NOD) mice: $A$ longitudinal study. Clin Exp Immunol 60:622-630.

Mogensen CE, Keane WF, Bennett PH, Jerums G, Parving HH, Passa P, Steffes MW, Striker GE, and Viberti GC (1995). Prevention of diabetic renal disease with special reference to microalbuminuria (see comments). Lancet 346:1080-1084.

Odoni G and Ritz E (1999). Diabetic nephropathy: What have we learned in the last three decades? J Nephrol 12(Suppl 2):S120-S124.

Orikasa M, Matsui K, Oite T, and Shimizu F (1988). Massive proteinuria induced in rats by a single intravenous injection of a monoclonal antibody. J Immunol 141:807-814.

Putaala H, Sainio K, Sariola H, and Tryggvason K (2000). Primary structure of mouse and rat nephrin cDNA and structure and expression of the mouse gene. J Am Soc Nephrol 11:991-1001.

Reivinen J, Holthöfer H, and Miettinen A (1994). O-acetyl GD3 ganglioside in human peripheral blood T lymphocytes. Int Immunol 6:1409-1416.

Ruotsalainen V, Ljungberg P, Wartiovaara J, Lenkkeri U, Kestilä M, Jalanko H, Holmberg C, and Tryggvason K (1999). Nephrin is specifically located at the slit diaphragm of glomerular podocytes. Proc Natl Acad Sci USA 96:7962-7967.

Scivittaro V, Ganz MB, and Weiss MF (2000). AGEs induce oxidative stress and activate protein kinase C-beta(II) in neonatal mesangial cells. Am J Physiol Renal Physiol 278: F676-F683.

Suzuki D and Miyata T (1999). Carbonyl stress in the pathogenesis of diabetic nephropathy. Intern Med 38:309-314.

Tisch R, Yang XD, Singer SM, Liblau RS, Fugger L, and McDevitt HO (1993). Immune response to glutamic acid decarboxylase correlates with insulitis in non-obese diabetic mice (see comments). Nature 366:72-75.

Wang S, Mene P, and Holthöfer $\mathrm{H}$ (2001). Nephrin regulation by protein kinase C. J Nephrol 15:1843-1845. 